\title{
Feeding Ecology of Taruca (Hippocamelus antisensis) Populations during the Rainy and Dry Seasons in Central Peru
}

\author{
Carla Gazzolo ${ }^{1,2}$ and Javier Barrio ${ }^{2}$ \\ ${ }^{1}$ Laboratorio de Ecología, Universidad Nacional Agraria La Molina, Lima 12, Peru \\ ${ }^{2}$ Centro de Ornitología y Biodiversidad (CORBIDI), Calle Santa Rita 105, Oficina 2, Urbanización Huertos de San Antonio, \\ Lima 33, Peru \\ Correspondence should be addressed to Javier Barrio; javbar@gmail.com
}

Received 6 October 2015; Revised 19 January 2016; Accepted 20 January 2016

Academic Editor: Eugene S. Morton

Copyright (C) 2016 C. Gazzolo and J. Barrio. This is an open access article distributed under the Creative Commons Attribution License, which permits unrestricted use, distribution, and reproduction in any medium, provided the original work is properly cited.

\begin{abstract}
Tarucas (Hippocamelus antisensis) live in rocky areas in the Andes, from northern Peru to northern Argentina. Microhistological analyses on their feeding ecology during the rainy and dry seasons were done at a National Park and a Landscape Reserve. The diet was diverse and more than 50 species were identified from the feces. Grass species were most often detected as eaten by taruca during the rainy season comprising near $70 \%$ of the consumed fragments with 35 plant species identified as eaten then. In the dry season, around 50 species were identified as eaten by tarucas, mostly dicotyledonous. The main species consumed in both seasons were Werneria nubigena, Poa gymnantha, Senecio comosus, and Ephedra americana. The ecological density was an intermediate value compared to other observed values in Peru. This is the first study to find the importance of grasses for tarucas, selected when soft, during the rainy season. A possible overlap with domestic ungulates' diets should be explored, helping the conservation of taruca and generating an adequate management of the species and the ecosystem. There is a change in the palatable offer of food items during the rainy season, when most of the Gramineae species are tender.
\end{abstract}

\section{Introduction}

Tarucas (Hippocamelus antisensis) live in the Andes, from northern Peru to northern Argentina and Chile, ranging from $2,000-3,500 \mathrm{~m}$ elevation at the south to $3,800-5,000 \mathrm{~m}$ in Peru and Bolivia [1-3]. Tarucas live along the Puna grassland biome $[1,2,4,5]$, and there is a marked breeding season during the austral and rainy summer season in the Andes [1]. In Peru, taruca shares its habitat with wild and domestic ungulates [6]. However, domestic ungulates might both compete with taruca for food and space affecting their populations [7] and modify the landscape, adding disturb on taruca populations. The presence of free roaming and shepherded ungulates is one of the threats why the taruca is listed as "vulnerable" in Peru [8] and the IUCN [9]. Cattle presence was identified as negative for the taruca related to space displacement [7].

A trustworthy assessment of the variety of foods consumed by taruca is essential to understand its ecology and to assess the threats generated by human activities such as cattle and sheep ranching. Data from direct observations indicate that tarucas mainly feed on small dicotyledon plants that grow near the ground instead of the abundant Andean bunch-grasses, especially during the dry season $[6$, 10, 11]. Microhistological analyses on samples from Huascaran National Park, central Andes of Peru, showed that the Gramineae species eaten by taruca during the breeding rainy season comprised around 57\% of the eaten items [12]. Yearround collection of pellets at Parinacota, northern Chile, only identified Gramineae species in pellets collected during the rainy season [5], but in an insignificant percentage.

Here we widen the scope on taruca feeding ecology during the rainy season in the southern part of Huascaran National Park, Peru, and provide data on its feeding ecology during the nonbreeding dry season at a sheep production ranch inside the Nor Yauyos-Cochas Landscape Reserve, Peru, and on the relative use of tarucas of areas in its patchy distribution. The increase of the understanding of taruca nutrition, as well as the determination of continuous and 


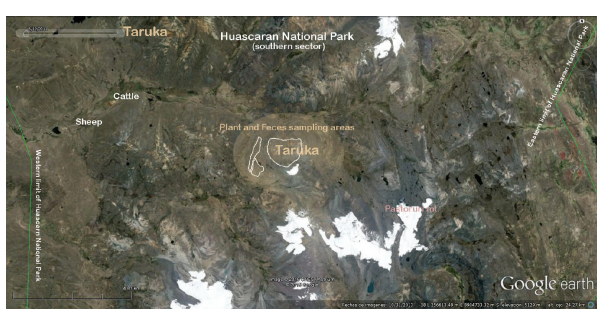

Huascaran National Park

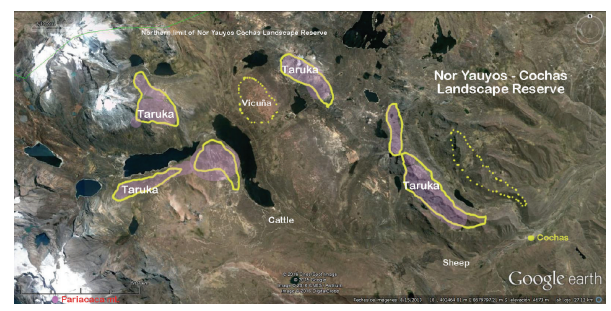

Nor Yauyos-Cochas Landscape Reserve

FIGURE 1: Map of research areas. Buff shadowed area in Huascaran National Park and light pink shadowed areas in Nor Yauyos-Cochas Landscape Reserve are the areas where plant and feces were collected.

temporal use of areas, will increase the effectiveness of ecologists and wildlife managers by providing a diet and occupation pattern that can be compared to domestic ungulates in the area and determine if animal husbandry is also displacing this native deer.

\section{Methods}

2.1. Study Areas. The studies were carried out in Quebrada Rajucolta, in the south of Huascaran National Park, central Peru, and the SAIS Tupac Amaru, a production ranch property of several Andean communities, located inside the Nor Yauyos-Cochas Landscape Reserve, west from the city of Huancayo and east from Lima, Peru. The area evaluated was situated to the west of the SAIS, almost at the center of the Landscape Reserve. One large area in Quebrada Rajucolta, south of Huascaran National Park in March 2003, and eight (8) different areas were sampled in the Nor YauyosCochas Landscape Reserve from June 26th to July 10th, 2007; pellet and vegetation samples were collected from all areas. The coordinates of the study area in Quebrada Rajucolta, Huascaran National Park, were $-9.8958^{\circ}$ and $-77.2333^{\circ}$, at $4700 \mathrm{~m}$ of elevation. The base headquarter in the Nor YauyosCochas Landscape Reserve was at $-11.97306^{\circ}$ and $-75.80722^{\circ}$, placed at $4060 \mathrm{~m}$ (Figure 1).

The landscape is dominated by high altitude rolling hills mostly covered by bunch grasses, alternated with steep slopes, where rocky areas dominate. The highest peaks are covered with snow at elevations above $5000 \mathrm{~m}$. Most areas along the main roads on the Rajucolta and the Cocha river valleys are used for sheep and cattle grazing, while high hills or undulated terrain on mountaintops is exploited as alpaca grazing lands and used by wild vicuña herds.

2.2. Microhistological Analyses. Among the methodologies used to evaluate ruminant diets, the most convenient for low density and shy wild ungulates is based on fecal microhistological analysis $[13,14]$. The microhistological procedures in the lab for the analysis of both the vegetative samples and the pellet samples follow protocols that had been already used by the main author [12] and are based on procedures intensively used to determine the botanical composition of the diets of North American herbivore species [15-18]. These procedures

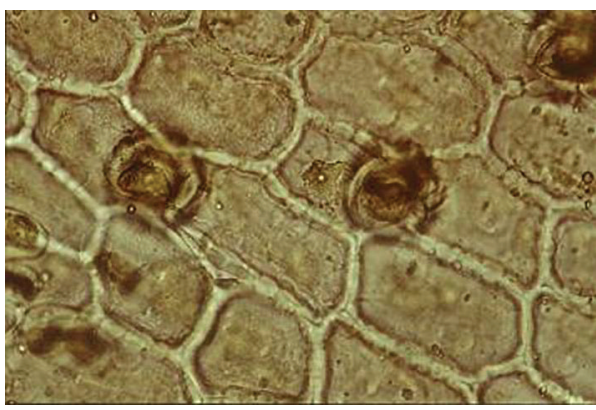

Figure 2: Tissue sample from Werneria sp.

allow measuring plant species percentages in the diet of specific ungulates by determining the percentages of plant tissues found in the samples $[19,20]$. This technique needs previous training on the epidermic characteristics of the plant species present in the study area and knowledge on plant tissues [21-23].

Most different plant species and fresh taruca pellet groups were collected from the study area. Eighty samples of plants were collected in the field and identified in the lab. Plant species were later identified at the herbarium of the Universidad Nacional Agraria La Molina and classified based on the Magnoliophyta classification system from Cronquist [24]. Some species of the families Poaceae, Asteraceae, and Malvaceae were identified by experts on those families. Tissue fragments were cut from the plant samples to build a reference pattern with tissues from the epidermis of all species collected. The tissues were soaked and boiled in 5\% sodium hydroxide for 5 minutes [25]; afterward, the epithelium was placed on a microscope slide with tweezers. Soon after, it was tinted with safranin at $1 \%$. The tissues were photographed through the microscope to create the reference pattern (e.g., Figure 2) in order to compare them with remains of plant tissues found in the feces.

Twenty-five fresh pellet groups were collected from all visited areas, so that they will correspond to the dry season. Old dry pellets were not collected, as would be difficult to determine deposition dates. Pellets were immersed in $70^{\circ}$ alcohol inside plastic ziplock bags. In the lab, a single pellet was selected from each pellet group (Figure 3). 


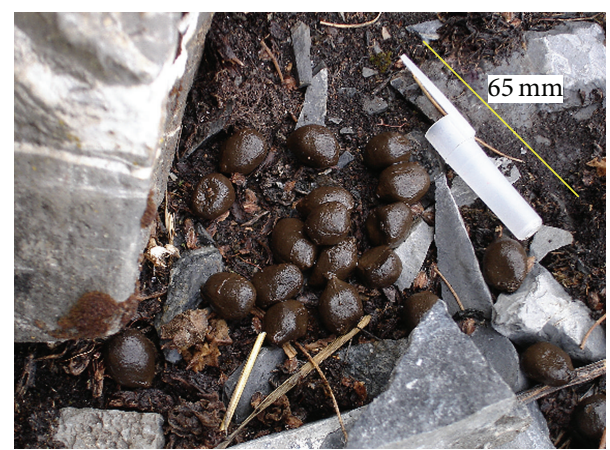

Figure 3: Pellet group collected in the field, only one was later selected by chance. The pen cap is displayed for size comparison.

The pellet samples were treated in the Animal Physiology Laboratory at the La Molina National Agrarian University, Lima, to eliminate mucous content and purify remnant fragments of epidermis tissue from the digestive process. Then, they were dried in an oven at $60^{\circ} \mathrm{C}$, to avoid fungal infection [26]. The protocol elaborated by Cosse [27] was followed in this case.

This protocol considers the use of sodium hydroxide and sodium hypochlorite. It has been proved that both substances improve the amount of identifiable fragments [16, 28, 29]. One gram of each sample was weighed and diluted in $10 \mathrm{~mL}$ of distilled water with the help of a mortar. The resulting mix was centrifuged at maximum speed for 5 seconds and the overfloating was discarded. After that, $10 \mathrm{~mL}$ of $\mathrm{NaOH}$ at $5 \%$ was added and boiled for 10 minutes. Still warm, a sodium hypochlorite suspension ( $10 \%$ chlorine) was added in a 1:6 proportion. After resting the product for 5 minutes, it was washed over $100 \mu$ mesh, with warm water. After that, $10 \mathrm{~mL}$ of $75 \%$ alcohol was added, and it was tinted with $1 \%$ safranin.

A squared slide was used for the observation and analysis of the fragments. For each sample, three repetitions were done, dropping 3-5 drops of safranin solution per repetition. The slides were observed through a binocular microscope with 40 and 100x magnification. The identification of the fragment was realized comparing the structures with the reference pattern elaborated previously. The fragments were counted with systematic sweeps along the length and width of the slide to avoid duplication, as it was suggested by Green [30].

2.3. Population Analysis. The rough topography makes transect techniques very difficult in this area, considering the complication of installing transects in a random or systematic pattern, as recommended by Buckland et al. [31]. The density was estimated by the population size of tarucas in each area (number of different individuals sighted plus the ones inferred by tracks), divided by the area used. The area used was calculated as the polygon enclosing all tracks and pellet groups found, plus $100 \mathrm{~m}$ of buffer zone around it. Areas with continuous use were defined by the presence of tracks at least from five days.

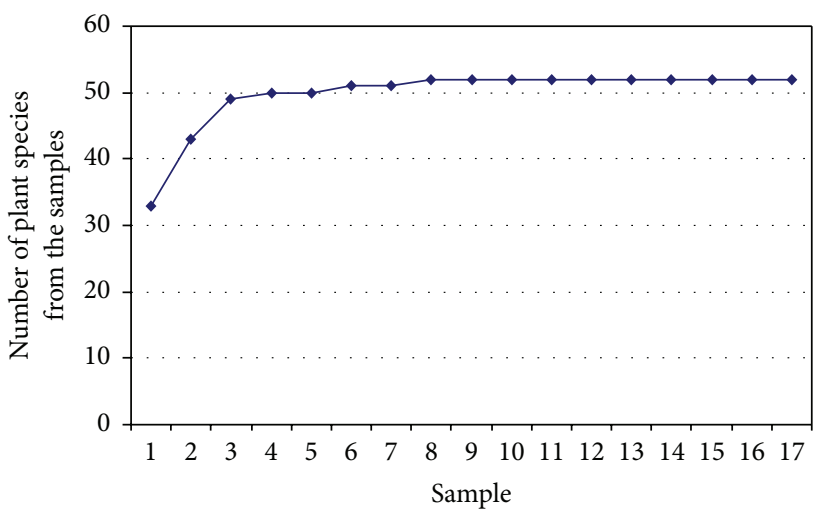

FIgURE 4: Plant species accumulation curve based on number of analyzed samples.

\section{Results and Discussion}

\subsection{Feeding Ecology}

3.1.1. Collection of Species of Plants. Fifty-seven plant species out of around 65 plant species present in the area and one hundred and one pellet groups were collected in Quebrada Rajucolta, Huascaran National Park in the year 2003, to use them for the microhistological analysis. Given that only 14 pellets were needed to stabilize the accumulation curve of new species, a smaller sample of pellets was used in 2007. Then, fifty-four plant species and twenty-five pellet groups were collected in the field and used for the microhistological analysis. These species correspond to four plant divisions, at least to 15 families and more than 50 species (Table 1).

3.1.2. Sample Size. Twenty-five pellet groups were collected in the field in 2007. A species accumulation curve was developed to analyze if the sample size was enough to establish taruca's diet components. A total of 20 samples were analyzed in 2003 and 17 in 2007. However, after the fourteenth sample no new species were found in the feces in the 2003 data and after the eighth in the 2007 data (Figure 4). A probability analysis to test the possibility on finding new species in the diet resulted in $1.5 \%$ after sample 15 . Therefore, 17 was an adequate number to analyze.

3.1.3. Microhistological Analyses. A total of 973 fragments were identified from the tissues collected in the rainy season of 2003. The species detected with more than $4 \%$ of the fragments each in the rainy season were Poa gymnantha, Luzula racemosa, Bromus villosissimus, Agrostis sp., Werneria nubigena, Distichia muscoides, Trisetum spicatum, Poa spicigera, Senecio comosus, Ephedra americana, and Poa candamoana.

A total of 5,939 fragments were identified from the tissues collected from the feces in the dry season of 2007. The identified structures included pollen grains, epidermis, and pteridophyte sporangia. From these fragments, 124 corresponded to nonanalyzed pollen grains. The 5,815 remaining fragments included 130 unidentified ones, left as NN. The identified tissues in the fragments added 5,685. A total 
TABLE 1: Plant species collected and percentage (from the total identified) of fragments of the species most often detected as consumed by taruca in the dry season.

\begin{tabular}{|c|c|c|c|}
\hline Division & Family & Species & $\%$ \\
\hline Bryophyta & $*$ & $*$ & 7.5 \\
\hline Pteridophyta & * & $*$ & 0.4 \\
\hline Gnetophyta & Ephedraceae & Ephedra americana & 6.2 \\
\hline \multirow[t]{34}{*}{ Magnoliophyta } & Urticaceae & Urtica sp. & - \\
\hline & & Arenaria sp. & 3.7 \\
\hline & Caryophyllaceae & Cerastium sp. & 0.7 \\
\hline & & Paronychia andina & 1.3 \\
\hline & & Sp. 21 & 3.0 \\
\hline & Polygonaceae & $\begin{array}{c}\text { Muehlenbeckia } \\
\text { volcanica }\end{array}$ & - \\
\hline & Rosaceae & Alchemilla pinnata & 7.7 \\
\hline & Fabaceae & $\begin{array}{l}\text { Lupinus affinis } \\
\text { microphylla }\end{array}$ & 5.3 \\
\hline & Gentianaceae & Gentianella sp. & 0.5 \\
\hline & Valerianaceae & Valeriana sp. & - \\
\hline & Geraniaceae & $\begin{array}{l}\text { Sp. X (not } \\
\text { collected) }\end{array}$ & 0.4 \\
\hline & Plantaginaceae & $\begin{array}{c}\text { Plantago } \\
\text { lamprophylla }\end{array}$ & 2.6 \\
\hline & & Baccharis alpine & 0.4 \\
\hline & & $\begin{array}{c}\text { Baccharis sp. aff. } \\
\text { genistelloides }\end{array}$ & 3.1 \\
\hline & & $\begin{array}{l}\text { Baccharis } \\
\text { caespitosa }\end{array}$ & 0.8 \\
\hline & & Coreopsis sp. & 0.3 \\
\hline & & Chuquiraga spinosa & - \\
\hline & & Mutisia sp. & 0.2 \\
\hline & & $\begin{array}{l}\text { Parastrephia } \\
\text { quadrangularis }\end{array}$ & 0.5 \\
\hline & Asteraceae & $\begin{array}{c}\text { Perezia } \\
\text { coerulescens }\end{array}$ & 0.3 \\
\hline & & Senecio canescens & 0.4 \\
\hline & & Senecio comosus & 6.5 \\
\hline & & $\begin{array}{c}\text { Senecio } \\
\text { hohenackeri }\end{array}$ & 4.8 \\
\hline & & $\begin{array}{c}\text { Senecio } \\
\text { macrorrhizus }\end{array}$ & 1.7 \\
\hline & & Senecio nutans & 1.1 \\
\hline & & Senecio sp. 16 & 2.0 \\
\hline & & Senecio sp. 50 & 0.5 \\
\hline & & Senecio sp. & 3.4 \\
\hline & & Werneria nubigena & 4.5 \\
\hline & & $\begin{array}{l}\text { Werneria } \\
\text { orbignyana }\end{array}$ & 0.1 \\
\hline & & Werneria pygmaea & - \\
\hline & & Werneria sp. & 1.8 \\
\hline & & $\begin{array}{c}\text { Xenophyllum } \\
\text { dactyllophyllum }\end{array}$ & 4.4 \\
\hline & & Xenophyllum sp. & 一 \\
\hline
\end{tabular}

TABLE 1: Continued.

\begin{tabular}{|c|c|c|c|}
\hline Division & Family & Species & $\%$ \\
\hline & Liliaceae & Bomarea dulcis & 0.3 \\
\hline & \multirow{9}{*}{ Juncaceae } & Distichia muscoides & 2.8 \\
\hline & & Luzula racemosa & 1.3 \\
\hline & & Agrostis tolucensis & 0.6 \\
\hline & & Agrostis ovata & - \\
\hline & & Agrostis sp. & 1.5 \\
\hline & & $\begin{array}{c}\text { Calamagrostis } \\
\text { amoena }\end{array}$ & - \\
\hline & & $\begin{array}{c}\text { Calamagrostis } \\
\text { brevifolia }\end{array}$ & 0.3 \\
\hline & & $\begin{array}{l}\text { Calamagrostis } \\
\text { eminens }\end{array}$ & 1.1 \\
\hline & & $\begin{array}{c}\text { Calamagrostis } \\
\text { macrophylla }\end{array}$ & 0.5 \\
\hline & \multirow{11}{*}{ Poaceae } & $\begin{array}{c}\text { Calamagrostis } \\
\text { spicigera }\end{array}$ & 0.6 \\
\hline & & $\begin{array}{c}\text { Calamagrostis } \\
\text { nitidula }\end{array}$ & 3.4 \\
\hline & & $\begin{array}{c}\text { Calamagrostis } \\
\text { rigida }\end{array}$ & 0.2 \\
\hline & & $\begin{array}{c}\text { Calamagrostis } \\
\text { tarmensis }\end{array}$ & - \\
\hline & & $\begin{array}{c}\text { Calamagrostis } \\
\text { vicunarum }\end{array}$ & 2.4 \\
\hline & & Calamagrostis sp. & 1.6 \\
\hline & & $\begin{array}{c}\text { Dissanthelium } \\
\text { calycinum } \\
\text { mathewsii }\end{array}$ & 1.3 \\
\hline & & Festuca inarticulata & - \\
\hline & & Hordeum muticum & 0.4 \\
\hline & & $\begin{array}{c}\text { Nassella } \\
\text { brachyphylla }\end{array}$ & 0.6 \\
\hline & & Poa gymnantha & 3.6 \\
\hline
\end{tabular}

of 303 fragments corresponded to the vegetative divisions Bryophyta (mosses) and Pteridophyta (ferns). In these two cases, the identification was done only to division level, given the similarity of the remains in the species of each division. Most of the fragments were identified to species level; however, in some few cases, the identification only reached genus or family (1 case). The only Gnetophyta, Ephedra americana, is probably the easiest species to identify when looking at the tissues, and its percentage in the diet is probably the best estimate among all the species. This species is found usually above $4600 \mathrm{~m}$ of elevation.

At family level, the highest percentage of identified fragments in the pellets collected in the dry season corresponded to Asteraceae, with $41 \%$, and Poaceae, with $35 \%$. Of the species found in the diet in the dry season of 2007, the most often detected was Alchemilla pinnata (Rosaceae), with a frequency of less than $8 \%$. At genus level, at least 8 species of Senecio were consumed, adding to more than $20 \%$ of the diet, with Senecio comosus often identified in both seasons. Eight 
species of Calamagrostis included around $10 \%$ of the diet in the dry season.

The main species consumed in both seasons were Werneria nubigena, Poa gymnantha, Senecio comosus, and Ephedra americana, adding to $21-25 \%$ of the diet. The diet was diverse and over 50 species were identified from the feces collected in both seasons. Although mosses (Bryophyta) were not identified to genus or family level, as a group they were a very important part of the diet in both seasons, with around 4$7.5 \%$ of the detected fragments at each season. Some tissues were identified from plants collected elsewhere. Gramineae included around $70 \%$ of the most often recorded fragments in the rainy season and $20 \%$ of the diet in the dry season.

It is important to notice that most of the species of plants found and collected in the field were represented in the diet. This indicates that the taruca does not have a specialized diet on few plant species or on a specific group of plants. However, its diet seems to be specialized on palatable species, changing preferences based on availability throughout the year, and then, the taruca might be a selective species if its diet is based only on tender and nutritious parts of the plants. Most of the genera were not circumscribed to the distribution of the taruca. A large part of the genera and species included here have been previously reported in taruca's diet by one of the authors [12]. As was already explained, the estimation of plant abundances does not allow for calculations on food preferences by the taruca given that plant species ingestion is not proportional to defecation [32]. There is uneven fragmentation of different species during the digestion.

3.2. Population, Density, and Hunting. Tarucas, or taruca signs, were found in all areas sampled. In Quebrada Rajucolta at Huascaran National Park there were fresh tracks every sampling dates, indicating continuous use by the species. Four of the sampled areas showed continuous use by the tarucas: two had signs of temporal or seasonal use, and two had signs of occasional use. In total, seventeen tarucas were observed directly in five separate observations during the dry season, and at least other ten were inferred from tracks. All observations, tracks, and pellets occurred at more than 4500 meters above sea level, up to 4930 meters. The availability and distribution of the habitat used are based on the presence of basic resources such as food, water and cover, and adaptation to the physical and weather conditions [33]. The areas that showed occasional use included topography and habitat characteristics that did not correspond with areas usually occupied by tarucas. In those areas, tarucas were not found; instead, they were populated by vicuñas, with some taruca tracks indicating that they travel through them to reach preferred habitat types.

The areas used by tarucas were mainly composed of rocky areas and steep slopes (Figure 5). This habitat type has been defined as the preferred by the species $[4,6]$. The ecological density-calculated by the total number of individuals estimated at each used area and the extension of the areas used by the species-was around $1 \mathrm{ind} / \mathrm{km}^{2}$. This density can be considered a usual value for areas under no or only moderate illegal hunting [6]. However, ecological densities

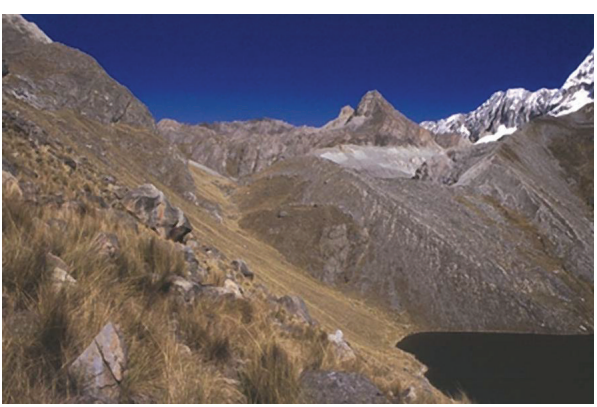

FIGURE 5: One of the areas that had evidence of continuous use by taruca, note topographic and habitat preferred by the species. Adult and young females were observed in the area.

above $1 \mathrm{ind} / \mathrm{km}^{2}$ have been found in areas where poaching is negligible $[4,6]$. Currently, illegal hunting seems to be infrequent in the Landscape Reserve, as some cartridges and horse tracks were found in two of the areas with continuous use by tarucas but unimportant in the National Park.

There is space displacement of tarucas by cattle, as has been found in Rio Abiseo National Park [7], but no analysis on feeding competition has been done between domestic stock and tarucas. More data on vegetation throughout the year and on the distribution range of the taruca and analyses on feeding preferences are needed to determine the changes of plant species offer and preferences throughout the year. We have to recognize that there is a change in the palatable offer of food items during the rainy season, when most of the Gramineae species are tender.

\section{Conflict of Interests}

The authors declare that there is no conflict of interests regarding the publication of this paper.

\section{Acknowledgments}

The authors wish to acknowledge the Asociación Cinegética del Peru (ASOCIPE), for the support and funding. Also they wish to acknowledge La Molina National Agrarian University Ecology and Processes Biology Laboratory for the use of its facilities. And last but not least, thanks are due to the local people that accompanied us in the field.

\section{References}

[1] J. Barrio, "Hippocamelus antisenis," Mammalian Species, vol. 45, no. 901, pp. 49-59, 2013.

[2] H. Jungius, "Beobachtungen am weißwedelhirsch und an anderen cerviden in Bolivien," Zeitschrift für Säugetierkunde, vol. 39, pp. 373-383, 1974.

[3] J. Thornback and M. Jenkins, The IUCN Mammal Red Data Book. Part 1: Threatened Mammalian Taxa of the Americas and the Australasian Zoogeographic Region (Excluding Cetacea), IUCN, Gland, Switzerland, 1982.

[4] J. Merkt, "Reproductive seasonality and grouping patterns of the north Andean deer or taruca (Hippocamelus antisensis) in 
southern Peru," in Biology and Management of the Cervidae, C. Wemmer, Ed., pp. 388-401, Smithsonian Institution Press, Washington, DC, USA, 1987.

[5] W. Sielfeld, C. Carrasco, G. González, J. Torres, A. Carevic, and I. Lanino, "Estudio de la taruca (Hippocamelus antisensis) en Chile," Proyecto CONAF/PNUD/FAO-CHI/83/017, Universidad Arturo Prat, Iquique, Chile, 1988.

[6] J. Barrio, "Población y hábitat de la taruka en la Zona Reservada Aymara-Lupaca, Perú," in Manejo y Conservación de Fauna Silvestre en América Latina, T. Fang, O. Montenegro, and R. Bodmer, Eds., pp. 453-460, Editorial Instituto de Ecología, La Paz, Bolivia, 1999.

[7] J. Barrio, "Possible cattle influence on the population of two deer species at the highlands of Rio Abiseo National Park, Peru," IUCN Deer Specialist Group News, vol. 19, pp. 6-9, 2004.

[8] MINAGR (Ministerio de Agricultura), "Aprueban categorización de especies amenazadas de fauna silvestre y prohíben su caza, captura, tenencia, transporte o exportación con fines comerciales El Peruano, Normas Legales. 22 de setiembre del 2004," Decreto Supremo 034-2004-AG, 2004.

[9] J. Barrio and N. Ferreyra, "Hippocamelus antisensis. The IUCN Red List of Threatened Species," Version 2014.3, 2008, http:// www.iucnredlist.org/.

[10] Asociación Peruana para la Conservación de la Naturaleza (APECO), Evaluación Preliminar del Estado de la Población de Tarucas Hippocamelus antisensis en el Parque Nacional del Río Abiseo (PNRA) y de sus Requerimientos de Conservación, APECO, Cooperación Técnica Holandesa-Embajada de los Países Bajos, Miraflores, Perú, 1996.

[11] N. Roe and W. Rees, "Preliminary observations of the taruca (Hippocamelus antisensis: Cervidae) in southern Peru," Journal of Mammalogy, vol. 57, no. 4, pp. 722-730, 1976.

[12] C. Gazzolo, "Botanical composition of taruka (Hippocamelus antisensis) diet during the rainy season in Huascaran National Park, Peru," in Proceedings of the 6th International Deer Biology Congress, L. Bartoš, A. Dušek, R. Kotrba, and J. BartošovaVíchová, Eds., p. 216, Prague, Czech Republic, 2006.

[13] R. G. Anthony and N. S. Smith, "Comparison of rumen and fecal analysis to describe deer diets," The Journal of Wildife Management, vol. 38, no. 3, pp. 535-540, 1974.

[14] J. L. Holechek, M. Vavra, and R. D. Pieper, "Botanical composition determination of range herbivore diets: a review," Journal of Range Management, vol. 35, no. 3, pp. 309-315, 1982.

[15] D. Sparks and J. Malechek, "Estimating percentage dry weight in diets using a microscopic technique," Journal of Range Management, vol. 21, no. 4, pp. 264-265, 1968.

[16] J. L. Holechek, "Sample preparation techniques for microhistological analysis," Journal of Range Management, vol. 35, no. 2, pp. 267-268, 1982.

[17] J. L. Holechek and R. Valdez, "Magnification and shrub stemmy material influences on fecal analysis accuracy," Journal of Range Management, vol. 38, no. 4, pp. 350-352, 1985.

[18] E. J. Stevens, S. J. Stevens, R. N. Gates, K. M. Eskridge, and S. S. Waller, "Procedure for fecal cuticle analysis of herbivore diets," Journal of Range Management, vol. 40, no. 2, pp. 187-189, 1987.

[19] R. B. Gill, L. H. Carpenter, R. M. Bartmann, D. L. Baker, and G. G. Schoonveld, "Fecal analysis to estimate mule deer diets," Journal of Wildlife Management, vol. 47, no. 4, pp. 902-915, 1983.

[20] G. Schaller, Wildlife of the Tibetan Steppe, University of Chicago Press, Chicago, Ill, USA, 1998.
[21] J. L. Holechek and B. Gross, "Training needed for quantifying simulated diets from fragmented range plants," Journal of Range Management, vol. 35, no. 5, pp. 644-647, 1982.

[22] S. Monge, "Descripción de las características epidérmicas de gramíneas del centro-este de Mendoza (Ñacuñán, Santa Rosa)," Revista Argentina de Producción Animal, vol. 9, pp. 57-68, 1989.

[23] K. Sanders, B. Dahl, and G. Scout, "Bite-count vs. fecal analysis for range animal diets," Journal of Range Management, vol. 33, no. 2, pp. 146-149, 1980.

[24] A. Cronquist, An Integrated System of Classification of Flowering Plants, Columbia University Press, New York, NY, USA, 1981.

[25] R. J. Putman, "Facts from faeces," Mammal Review, vol. 14, no. 2, pp. 79-97, 1984.

[26] J. W. Todd and R. M. Hansen, "Plant fragments in the feces of bighorns as indicators of food habits," The Journal of Wildlife Management, vol. 37, no. 3, pp. 363-366, 1973.

[27] M. Cosse, Dieta y solapamiento de la población de venado de campo (Ozotoceros bezoartticus, 1758) (Artiodactyla: Cervidae) [Tesis de Maestría en Biología, Opción Zoología], Programa de Desarrollo de las Ciencias Básicas (PEDECIBA). Universidad de la República, Montevideo, Uruguay, 2001.

[28] O. B. Williams, "An improved technique for identification of plant fragments in herbivore feces," Journal of Range Management, vol. 22, no. 1, pp. 51-52, 1969.

[29] M. Vavra and J. L. Holechek, "Factors influencing microhistological analysis of herbivore diets," Journal of Range Management, vol. 33, no. 5, pp. 371-374, 1980.

[30] M. J. B. Green, "Diet composition and quality in Himalayan musk deer based on fecal analysis," Journal of Wildlife Management, vol. 51, no. 4, pp. 880-892, 1987.

[31] S. Buckland, D. Anderson, K. Burnham, and J. Laake, Distance Sampling: Estimating Abundance of Biological Populations, Chapman and Hall, London, UK, 1993.

[32] M. L. McInnis, M. Vavra, and W. C. Krueger, "A comparison of four methods used to determine the diets of large herbivores," Journal of Range Management, vol. 36, no. 3, pp. 302-306, 1983.

[33] M. L. Morrison, B. G. Marcot, and R. W. Mannan, WildlifeHabitat Relationships: Concepts and Applications, The University of Wisconsin Press, Madison, Wis, USA, 1998. 

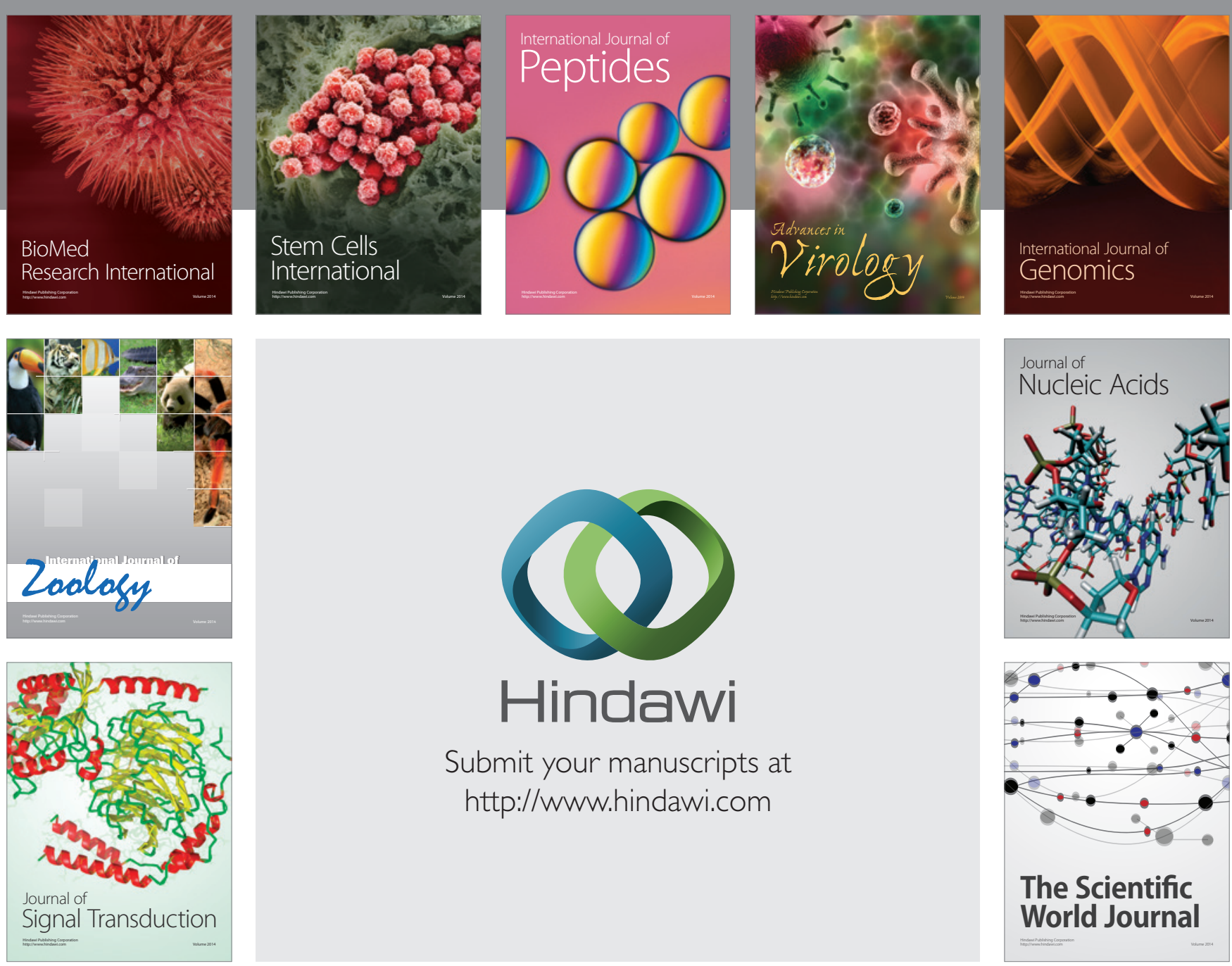

Submit your manuscripts at

http://www.hindawi.com
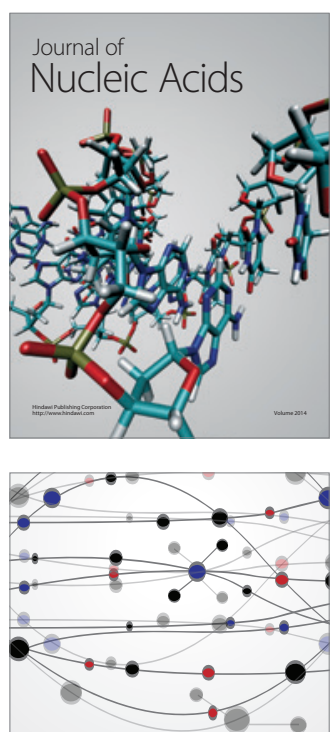

The Scientific World Journal
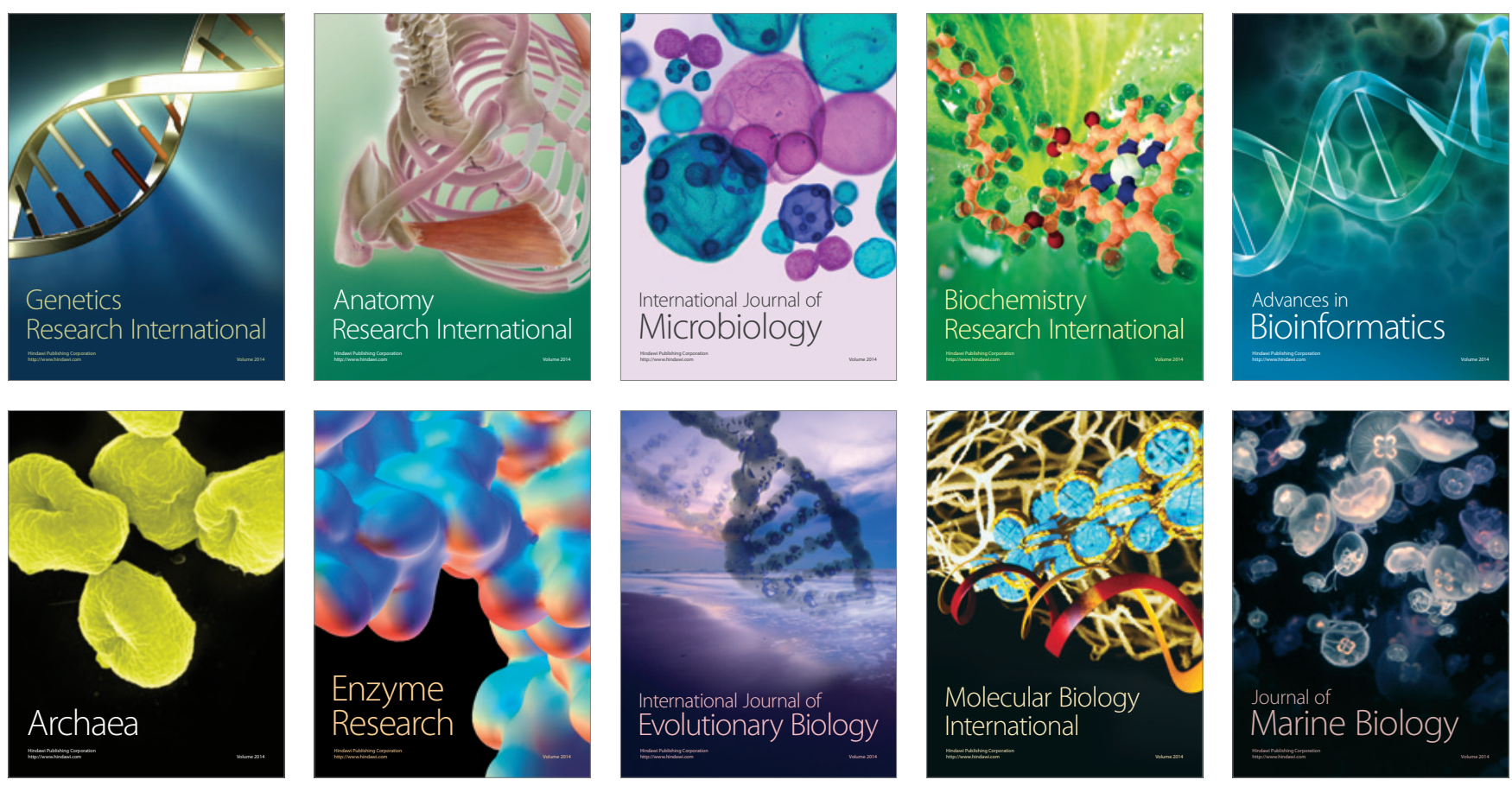